\title{
Novel 1-hydroxy-1,1-bisphosphonates derived from indazole: synthesis and characterization
}

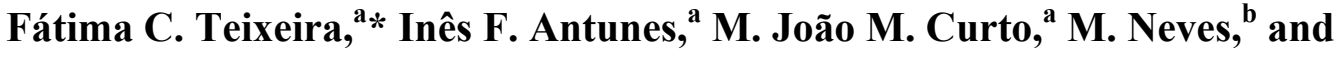 \\ António P.S. Teixeira ${ }^{c, d}$ \\ a INETI - Departamento de Tecnologia de Indústrias Químicas, Estrada do Paço do Lumiar, 22, \\ 1649-038 Lisboa, Portugal \\ ${ }^{b}$ Instituto Tecnológico e Nuclear, Estrada Nacional 10, 2686-953 Sacavém, Portugal \\ ${ }^{c}$ Centro de Química de Évora e Departamento de Química, Universidade de Évora, R. Romão \\ Ramalho, 59, 7000-671 Évora, Portugal \\ ${ }^{d}$ Centro de Química Estrutural, IST, Av. Rovisco Pais, 1, 1049-001 Lisboa, Portugal \\ E-mail: fatima.teixeira@ineti.pt
}

\begin{abstract}
Bisphosphonates (BPs) are an important class of drugs used in the treatment of abnormal calcium metabolism diseases. The first syntheses of bisphosphonates derived from indazole, substituted at the $\mathrm{N}-1, \mathrm{~N}-2$ and $\mathrm{C}-3$ positions are reported. The 1-hydroxy-1,1-bisphosphonates were synthesized from the corresponding carboxylic acid or acyl chloride compounds, by two different methods. These BPs have a side chain with different lengths $\left(\left(\mathrm{CH}_{2}\right)_{\mathrm{n}}, n=0-5\right)$ between the indazole ring and the bisphosphonate group.
\end{abstract}

Keywords: Bisphosphonates, indazole, N-1 and N-2 isomers, spectroscopic characterization

\section{Introduction}

Bisphosphonates (BPs) are an important class of drugs known by their broad spectrum of therapeutic applications in the treatment of diseases characterized by abnormal calcium metabolism, such as hypercalcemia, osteoporosis and tumor-associated osteolysis. ${ }^{1}$ BPs were first developed as pharmaceuticals in the mid-1960's and have been used as an effective treatment for Paget's disease. ${ }^{2}$ Since then, many BPs were synthesized and made commercially available due to their value in the treatment of disorders of bone mineral. ${ }^{3}$ These compounds have high affinity for calcium and therefore to target the bone mineral, where they appear to be internalized selectively by bone-reabsorbing osteoclasts and induce their apoptosis. ${ }^{4}$ BPs offer several advantages in treating osteoporosis since they are bone-tissue specific, have minimal side 
effects, have no known risk of carcinogenesis and have antiresorptive efficacy equivalent to, or even greater than estrogens. ${ }^{5}$

In addition, functional BPs showed anti-tumour properties which includes activity against bone metastases secondary to breast cancer ${ }^{6}$ and prostate cancer, ${ }^{7}$ inhibition of cell proliferation, invasion and adhesion to bone. ${ }^{8}$ They also showed to have applications in the inhibition of angiogenesis ${ }^{9}$ and as anti-inflammatory agents. ${ }^{10}$ BPs are also useful as novel ligands in welldefined radioactive metal complexes that can be used in magnetic resonance imaging and imagiology, scintigraphy and radiotherapy applications. ${ }^{11}$ Another property of these compounds under investigation is their chelating efficiency toward metal ions; several laboratories are developing BPs as chelating agents for the treatment of human metal intoxications. ${ }^{12}$

Chemically, BPs are structural analogues of pyrophosphonates in which the oxygen atom of $\mathrm{P}-\mathrm{O}-\mathrm{P}$ is replaced by a carbon atom, resulting in P-C-P bonds which are stable toward heat and chemical reagents, completely resistant to enzymatic degradation, and usually have low toxicity. ${ }^{1,13}$

The biological activities of these compounds are determined by the nature of the alkyl moiety bound to the bisphosphonic structure as well as the functional groups located on the alkyl chain, with the nitrogen-containing homologues, such as risedronate and zoledronate, being amongst the most potent BPs in the treatment of several bone diseases. The most potent BPs contains 1 or 2 nitrogen atoms in a heteroaromatic moiety linked via a small side chain to a geminal bisphosphonate group. Some of the heterocyclic-BPs are drugs commercially available, such as Actonel $^{\circledR}$ (risedronate sodium) and Zometa ${ }^{\circledR}$ (zoledronic acid). ${ }^{14,15}$ The BPs usually present a very low oral bioavailability due to the high hydrophilicity of their phosphonate groups. ${ }^{16}$

Indazole derivatives are pharmacologically important compounds and the indazole ring system forms the basis of several drug molecules. ${ }^{17}$ However, the chemistry of indazole remains less studied in comparison with other heteroaromatic compounds, such as indole or benzimidazole.

The indazole ring has two nitrogen atoms, like the $3^{\text {rd }}$ generation BPs, which can lead to an increased effect of BPs and can be functionalized with high selectivity at different positions. The length of the side chain and the different positions at the indazole ring, where it could be bonded, can afford a large number of indazolebisphosphonates, presenting a promising field to achieve new BPs with biological and therapeutical properties.

To the best of our knowledge, no BPs derived from indazole were synthesized. The aim of this work is to obtain new BPs derived from indazole with high potential biological/therapeutical activities.

Here, we report the synthesis and structural characterization of new indazole BPs substituted at different $\mathrm{C}$ - or $\mathrm{N}$ - positions of indazole rings, and with a side chain with different lengths $\left(\mathrm{CH}_{2}\right)_{\mathrm{n}} n=0-5$ from the bisphosphonate function to the nitrogen or carbon atom of the ring. 


\section{Results and Discussion}

\section{Synthesis}

The new 1-hydroxy-1,1-indazolebisphosphonates were prepared from the corresponding carboxylic acid derived from indazole, substituted at $\mathrm{N}-1, \mathrm{~N}-2$ and $\mathrm{C}-3$ positions, with a side chain with different length 1a-e, 4a-e, 6 and $\mathbf{8}$. The synthesis of carboxylic acids 1a-e and 4a-e, and their characterization were reported previously. ${ }^{18}$

Several methods for the synthesis of 1-hydroxy-1,1-bisphosphonates have been reported. ${ }^{19}$ The most used method involves the reaction of a carboxylic acid with phosphorus trichloride and phosphorous acid or phosphoric acid, followed by acidic hydrolysis (Method A). ${ }^{15,20}$ Recently, a modified Arbuzov reaction method was proposed by Lecouvey et al. ${ }^{21}$ This method involves the reaction of an acyl chloride with tris(trimethylsilyl)phosphite, followed by methanolysis (Method B). ${ }^{21}$

1-Hydroxy-1,1-indazolebisphosphonate derivatives 2a-e were prepared in moderate yield from the corresponding carboxylic acid derived from an indazole substituted at the $\mathrm{N}-1$ position 1a-e $(n=1-5)$, by treatment with a mixture of phosphoric acid and phosphorus trichloride, followed by acid hydrolysis (Table 1). The separation and purification of BPs were done by precipitation in acetone and methanol, being always a difficult and tedious process, as previously described by other authors. ${ }^{15}$

Table 1. Preparation of bisphosphonates $\mathbf{2 a - e}$ derived from indazole substituted at N-1 position<smiles>Cn1ncc2ccccc21</smiles>

1a-e i) $\mathrm{H}_{3} \mathrm{PO}_{4}(85 \%) / \mathrm{PCl}_{3}$

ii) $\mathrm{HCl}(9 \mathrm{~N})$

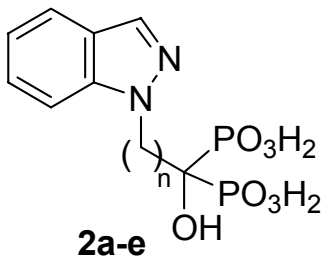

\begin{tabular}{ccc}
\hline Compound & $n$ & Yield (\%) \\
\hline 2a & 1 & 16 \\
2b & 2 & 60 \\
2c & 3 & 44 \\
2d & 4 & 62 \\
$\mathbf{2 e}$ & 5 & 50 \\
\hline
\end{tabular}

In the case of the compound $\mathbf{2 a}$, with a single methylene group, the yield of the reaction was very low. So, the Lecouvey's alternative method (Method B) was used. The acyl chloride 3a was prepared in situ, by reaction of the carboxylic acid 1a with thionyl chloride, which showed to be 
very unstable. The acyl chloride 3a reacted with tris(trimethylsilyl)phosphite, followed by methanolysis, to afford BP 2a, in 71\% yield (Scheme 1).

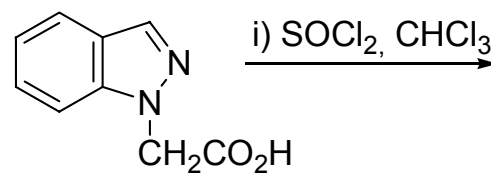

1 a

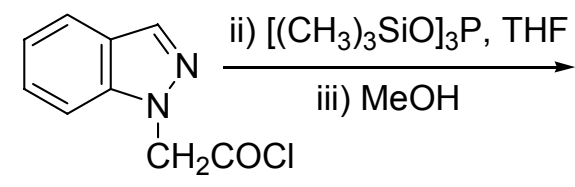

in situ

$3 a$

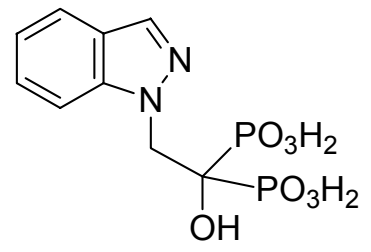

2a $71 \%$

\section{Scheme 1}

The 1-hydroxy-1,1-indazole-bisphosphonate derivatives 5a-e were also prepared by reaction of the corresponding carboxylic acid derived from indazole substituted at N-2 position 4a-e $(n=$ 1-5) with phosphorus trichloride and phosphoric acid, followed by acidic hydrolysis (Method A). However, the reactions afforded the BPs in low yields (exception for BP 5e, with $n=5$ ) (Table 2). In order to increase the yields of these syntheses, the Lecouvey's method (Method B) was used and the synthesis of compound $\mathbf{5 b}$ afforded these BP in 77\% yield, but compounds $\mathbf{5 a}$ and $\mathbf{5 c}$ were always isolated in low yields. The lower solubility of compounds $\mathbf{4 a}$ and $\mathbf{4 c}$, in the solvent used to prepare the corresponding acyl chloride and the lower stability of the acyl chloride should explain the low yield of BP 5a and BP 5c (Table 2).

Table 2. Preparation of bisphosphonates 5a-e derived from indazole substituted at N-2 position

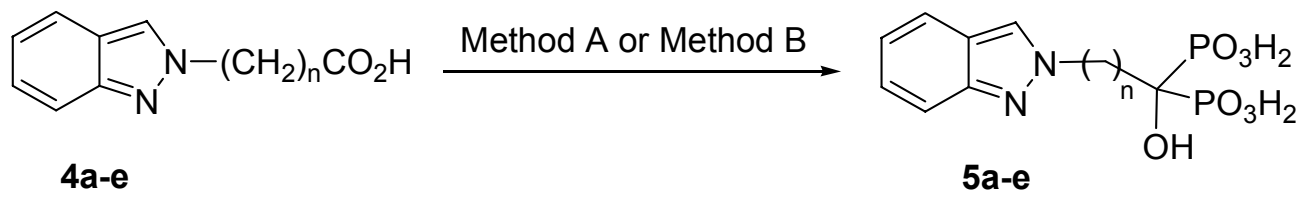

Method A: (i) $\mathrm{H}_{3} \mathrm{PO}_{4}(85 \%) / \mathrm{PCl}_{3}$; (ii) $\mathrm{HCl}(9 \mathrm{~N})$. Method B: (i) $\mathrm{SOCl}_{2}$ (4 eq.); (ii) $\left[\left(\mathrm{CH}_{3}\right)_{3} \mathrm{SiO}\right]_{3} \mathrm{P}$ (2 eq.); (iii) $\mathrm{MeOH}$

\begin{tabular}{cccc}
\hline Compound & $n$ & Method & Yield (\%) \\
\hline $\mathbf{5 a}$ & 1 & A & 6 \\
& & B & - \\
$5 \mathbf{b}$ & 2 & A & - \\
& & B & 77 \\
$5 \mathbf{c}$ & 3 & A & 17 \\
& & B & 17 \\
5d & 4 & A & 39 \\
\hline
\end{tabular}


1-Hydroxy-1,1-indazolebisphosphonate 7, prepared from the carboxylic acid 6, substituted at the indazole $\mathrm{C}-3$ position, was synthesized following the method of Lecouvey (Method B) ${ }^{21}$ The reaction of commercially available $1 H$-indazole-3-carboxylic acid $\mathbf{6}$ with $\mathrm{SOCl}_{2}$, to produce in situ the corresponding acyl chloride, followed by reaction with tris(trimethylsilyl)phosphite and hydrolysis, afforded the BP 7, as white powder, in $67 \%$ yield (Scheme 2).

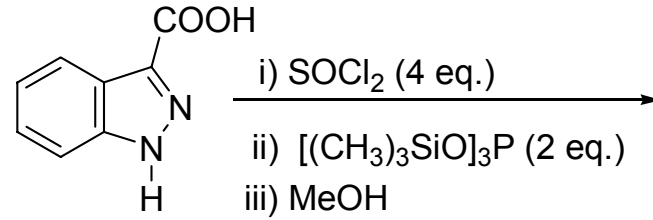

6

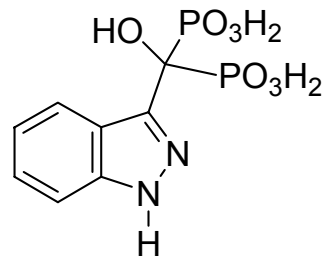

$767 \%$

\section{Scheme 2}

To increase the length of the alkyl side chain at the C-3 position, the carboxylic acid derivative $\mathbf{8}$ was synthesized according to literature procedures, from $o$-nitrobenzaldehyde, malonic acid and ammonium acetate in acetic acid. ${ }^{22}$ BP 9 was obtained by Lecouvey's method (Method B) from the corresponding carboxylic acid with 16\% yield (Scheme 3).

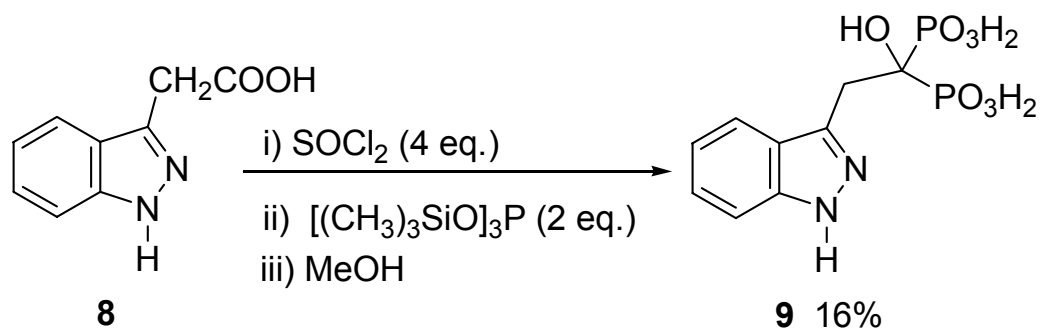

\section{Scheme 3}

\section{Spectroscopic characterization}

Compounds 2a-e, 5a-e, 7 and $\mathbf{9}$ were fully characterized by NMR (including bidimensional techniques), IR spectroscopy, mass spectrometry (low and high resolution) and elemental analysis.

The BPs were submitted to Electron Impact Ionization (EI) Mass Spectrometry, but most did not show the molecular ion. Fast Atom Bombardment (FAB) or Electrospray Ionization (ESI) methods were used to show the molecular ion of all BPs, which confirmed their proposed molecular formulae. The mass spectra showed characteristic fragment ions corresponding to the loss of $\mathrm{H}_{2} \mathrm{O}$ and $\mathrm{H}_{3} \mathrm{PO}_{3}$ fragments. ${ }^{23}$

The IR spectra of indazolebisphophonates showed the disappearance of the strong $\mathrm{C}=\mathrm{O}$ stretching band from the carboxylic acid (starting material) and the appearance of two strong 
characteristic bands at approximately $1250-1100$ and $1100-900 \mathrm{~cm}^{-1}$, due to the $v(\mathrm{P}=\mathrm{O})(1200$ $\left.1160 \mathrm{~cm}^{-1}\right), v(\mathrm{P}-\mathrm{OH})\left(\approx 1000\right.$ and $\left.\approx 925 \mathrm{~cm}^{-1}\right)$ and $\delta(\mathrm{POH})$ (around $1080 \mathrm{~cm}^{-1}$ ) bands of bisphosphonate group. ${ }^{24}$ A broad band with a maximum near $3400 \mathrm{~cm}^{-1}$ is attributed to the $\mathrm{O}-\mathrm{H}$ stretching band, in agreement with the presence of the bisphosphonate group. $\mathrm{C}-\mathrm{H}(\mathrm{Ar})$ and $\mathrm{CH}_{2}$ stretching bands are observed over this $v(\mathrm{O}-\mathrm{H})$ band. The $v(\mathrm{O}-\mathrm{H})$ band also overlaps with the very large and weak $v(\mathrm{PO}-\mathrm{H})$ and $\delta(\mathrm{POH})$ bands, with maximum around $2600-2800 \mathrm{~cm}^{-1}{ }^{24}$

The bisphosphonate structure of BPs was readily identified by analysis of NMR data. The unambiguous identification of isomers of indazolebisphosphonates derivatives substituted at N-1, $\mathrm{N}-2$, and C-3, was carried out by ${ }^{1} \mathrm{H}$ and ${ }^{13} \mathrm{C}$ NMR spectroscopy, including DEPT and APT, and two-dimensional NMR techniques (HETCOR, COSY, HSQC and HMBC).

The ${ }^{1} \mathrm{H}$ NMR and ${ }^{13} \mathrm{C}$ NMR spectra of N-1 and N-2 isomers of indazolebisphosphonates 2a-e and 5a-e are sufficiently different to be used as diagnostic tools for the position of substitution. The main resonances in the ${ }^{1} \mathrm{H}$ NMR spectra of BPs 2 a-e are: (i) the resonance of $\mathrm{CH}_{2}$ protons, which appears at $\delta 1.23-2.35 \mathrm{ppm}$, (ii) the resonance of $\mathrm{NCH}_{2}$ protons, which appears at $\delta$ 4.36$4.85 \mathrm{ppm}$, (iii) four resonances in the region of $\delta 7.11-7.75 \mathrm{ppm}$, relative to the aromatic ring protons, usually as two one proton doublets $(4-\mathrm{H}$ and $7-\mathrm{H})$ and two one proton triplets $(5-\mathrm{H}$ and $6-\mathrm{H}$ ), (iv) a singlet (or a doublet, with a very small coupling constant, $J 0.6 \mathrm{~Hz}$ ) at $\delta 7.99-8.12$, which corresponds to the 3-H proton.

The ${ }^{1} \mathrm{H}$ NMR spectra of BPs 5a-e also showed four resonances in the region $\delta$ 7.01-7.68 ppm, attributed to the aromatic ring protons, usually as two one proton doublets $(4-\mathrm{H}$ and $7-\mathrm{H})$ and two one proton triplets $(5-\mathrm{H}$ and $6-\mathrm{H})$; these resonances are generally 0.10 ppm upfield from the corresponding signals of the BPs 2a-e. The 3-H proton is observed as one proton singlet or doublet $(J 0.6 \mathrm{~Hz})$ at $\delta 8.30-8.42 \mathrm{ppm}$, which are generally $0.30 \mathrm{ppm}$ downfield from the signals of the BPs 2a-e. Both BPs 2a and 5a (all with $n=1$ ) present the $3-\mathrm{H}$ proton resonance $0.12 \mathrm{ppm}$ downfield relatively to the BPs $\mathbf{2 b}$-e and $\mathbf{5 b}$-e (with aliphatic side chains with more than one methylene group). Compounds $2 \mathbf{2 a}$ and $5 \mathbf{a}$ showed a triplet $\left({ }^{3} J_{\mathrm{H}, \mathrm{P}} \approx 10 \mathrm{~Hz}\right)$, at 4.85 and $4.90 \mathrm{ppm}$, respectively, due to the coupling of $\mathrm{NCH}_{2}$ protons with two phosphorous atoms, supporting the proposed structures of two equivalent phosphonate groups attached to the same carbon.

The indazoleBPs 7 and 9, derived from indazole substituted at C-3, showed four resonances in the region of $\delta 7.01-7.28 \mathrm{ppm}$ relative to the aromatic ring protons, as two one proton doublets (4-H and 7-H) and two one proton triplets $(5-\mathrm{H}$ and 6-H). The BP 7, which has the 1-hydroxy1,1-bisphosphonate group bonded to the pyrazole ring of the indazole, with no aliphatic side chain, present the doublet, relative to $\mathrm{H}-4,0.5 \mathrm{ppm}$ downfield relative to indazoleBP 9 (with a methylene group at the side chain). The ${ }^{1} \mathrm{H}$ NMR spectrum of BP 9 has a $\mathrm{CH}_{2}$ triplet $\left({ }^{3} J_{\mathrm{H}, \mathrm{P}} 14\right.$ $\mathrm{Hz}$ ) at $\delta 3.57 \mathrm{ppm}$, which confirmed the presence of two equivalent phosphonate groups attached to the same carbon.

${ }^{13} \mathrm{C}$ NMR spectroscopy also confirms the presence of the bisphosphonate group. The appearance of a quaternary carbon triplet (disappearing in DEPT-135 ${ }^{13} \mathrm{C}$ NMR spectra) at $\delta$ 71.1-74.3 ppm (with ${ }^{2} J_{\mathrm{C}, \mathrm{P}} 143-146 \mathrm{~Hz}$ ) supported the proposed structures with two phosphonate groups attached to the same carbon (P-COH-P) (Tables $3-5) .{ }^{13} \mathrm{C} N M R$ is also the best 
spectroscopic method for assigning the position of substitution, since the C-3, C-7 and C-7a showed different chemical shifts between the N-1, N-2 and C-3 isomers (Table 3-5). In N-1 substituted indazoleBPs spectra, C-3 was generally shifted downfield $10 \mathrm{ppm}$, and C-7 and C-7a were shifted upfield, relatively to the corresponding carbons in $\mathrm{N}-2$ substituted indazoleBPs. The C-3 substituted isomers (BPs 7 and 9) present $\mathrm{C}-7$ and C-7a with similar chemical shifts to the $\mathrm{N}-1$ isomers but the C-3 quaternary carbon atom was observed further downfield, at approximately $8 \mathrm{ppm}$.

Table 3. ${ }^{13} \mathrm{C}$ NMR data of compound N-1 isomers 2a-e

\begin{tabular}{|c|c|c|c|c|c|c|c|c|c|c|c|}
\hline \multirow[t]{2}{*}{$\mathrm{BP}$} & $n$ & \multicolumn{10}{|c|}{${ }^{13} \mathrm{C}$ NMR, $\delta$} \\
\hline & & Ar:C-7 & Ar:C-5 & Ar:C-4 & Ar:C-6 & Ar:C-3 & Ar:C-3a & Ar:C-7a & $\begin{array}{c}C(\mathrm{OH})- \\
\left(\mathrm{PO}_{3} \mathrm{H}_{2}\right)_{2}\end{array}$ & $\mathrm{NCH}_{2}$ & $\mathrm{CH}_{2}$ \\
\hline $2 a^{a}$ & 1 & 110.8 & 120.4 & 120.6 & 126.1 & 133.1 & 123.0 & 140.4 & $\begin{array}{c}73.2 \\
\left(\mathrm{t}, J_{\mathrm{CP}}\right. \\
143)\end{array}$ & 50.0 & \\
\hline $2 b^{a}$ & 2 & 109.5 & 120.4 & 121.0 & 126.0 & 132.6 & 123.6 & 138.8 & $\begin{array}{c}71.2 \\
\left(\mathrm{t}, J_{\mathrm{CP}}\right. \\
143)\end{array}$ & 44.3 & 33.6 \\
\hline $2 c^{a}$ & 3 & 109.8 & 120.3 & 120.9 & 125.9 & 132.3 & 123.5 & 139.1 & $\begin{array}{c}72.2 \\
\left(\mathrm{t}, J_{\mathrm{CP}}\right. \\
143)\end{array}$ & 49.0 & $24.3,30.6$ \\
\hline $2 d^{b}$ & 4 & 110.5 & $121.9^{*}$ & $122.2^{*}$ & 127.9 & 133.7 & 125.1 & 140.7 & $\begin{array}{c}74.2 \\
\left(\mathrm{t}, J_{\mathrm{CP}}\right. \\
146)\end{array}$ & 49.5 & $\begin{array}{c}22.2,31.7 \\
34.6\end{array}$ \\
\hline $2 e^{b}$ & 5 & 110.5 & $121.9^{*}$ & $122.2^{*}$ & 128.0 & 133.7 & 124.9 & 140.9 & $\begin{array}{c}74.3 \\
\left(\mathrm{t}, J_{\mathrm{CP}}\right. \\
146) \\
\end{array}$ & 49.4 & $\begin{array}{l}24.1,28.4, \\
30.7,35.0\end{array}$ \\
\hline
\end{tabular}

${ }^{\text {a }}$ Solvent for NMR: DMSO- $d_{6} .{ }^{\mathbf{b}}$ Solvent for NMR: MeOD- $d_{4} .{ }^{*}$ These assignments may be reversed.

The assignment of the C-3 isomers was supported by HSQC and HMBC spectra (Table 5). The connectivities found in these spectra allowed the full assignment of proton and carbon atoms, including the three quaternary carbon resonances. We may note that C-3 and C-7a have similar chemical shifts, but C-3, relative to C-7a, is observed upfield in BP 7 and downfield in BP 9.

The proton-decoupled ${ }^{31} \mathrm{P}$ NMR spectra of indazoleBPs $2, \mathbf{5 , 7}$ and $\mathbf{9}$ showed a single signal in the range of 15.4-21.1 ppm, which confirmed that two phosphorus atoms are magnetically equivalent. The chemical shifts of phosphorus atoms are similar between the corresponding isomers. The lower chemical shift is observed for indazoleBP 7, with no aliphatic side chain, 
with the phosphorus atoms connected to a carbon atom directly bonded to the aromatic indazole ring. The chemical shift generally increases with the increasing number of methylene groups in side chain.

Table 4. ${ }^{13} \mathrm{C}$ NMR data of compound N-2 isomers 5a-e in DMSO- $d_{6}$

\begin{tabular}{|c|c|c|c|c|c|c|c|c|c|c|c|}
\hline \multirow[b]{2}{*}{ BP } & \multirow[b]{2}{*}{$n$} & \multicolumn{10}{|c|}{${ }^{13} \mathrm{C}$ NMR, $\delta$} \\
\hline & & Ar:C-7 & Ar:C-5 & Ar:C-4 & Ar:C-6 & Ar:C-3 & Ar:C-3a & Ar:C-7a & $\begin{array}{c}C(\mathrm{OH})- \\
\left(\mathrm{PO}_{3} \mathrm{H}_{2}\right)_{2}\end{array}$ & $\mathrm{NCH}_{2}$ & $\mathrm{CH}_{2}$ \\
\hline $5 a$ & 1 & 116.6 & $121.3^{*}$ & $121.5^{*}$ & 127.6 & 126.8 & 121.2 & 147.8 & $\begin{array}{c}73.0 \\
\left(\mathrm{t}, J_{\mathrm{CP}} 141\right)\end{array}$ & 55.0 & \\
\hline $5 b$ & 2 & 116.8 & 120.9 & 120.6 & 125.4 & 123.5 & 121.4 & 147.9 & $\begin{array}{c}71.1 \\
\left(\mathrm{t}, J_{\mathrm{CP}} 143\right)\end{array}$ & 48.8 & 34.6 \\
\hline $5 c$ & 3 & 117.1 & 121.6 & 120.9 & 125.7 & 123.9 & 121.2 & 148.1 & $\begin{array}{c}72.3 \\
\left(\mathrm{t}, J_{\mathrm{CP}} 142\right)\end{array}$ & 53.7 & $25.2,30.5$ \\
\hline $5 d$ & 4 & 117.0 & 121.4 & 120.7 & 125.4 & 123.8 & 121.0 & 148.0 & $\begin{array}{c}72.4 \\
\left(\mathrm{t}, J_{\mathrm{CP}} 143\right)\end{array}$ & 52.9 & $\begin{array}{c}20.5,31.1 \\
33.0\end{array}$ \\
\hline $5 e$ & 5 & 116.9 & 121.0 & 120.7 & 125.5 & 124.0 & 121.4 & 147.9 & $\begin{array}{c}72.5 \\
\left(\mathrm{t}, J_{\mathrm{CP}} 143\right)\end{array}$ & 52.8 & $\begin{array}{l}22.6,26.9 \\
30.1,33.3\end{array}$ \\
\hline
\end{tabular}

* These assignments may be reversed.

Table 5. ${ }^{13} \mathrm{C}$ NMR data of compounds 7 and 9 in DMSO- $d_{6}$

\begin{tabular}{cccccccccc}
\hline & \multicolumn{7}{c}{${ }^{13} \mathrm{C} N M R, \delta$} \\
\cline { 2 - 9 } & Ar:C-7 & Ar:C-5 & Ar:C-4 & Ar:C-6 & Ar:C-3 & Ar:C-3a & Ar:C-7a & $C(\mathrm{OH})\left(\mathrm{PO}_{3} \mathrm{H}_{2}\right)_{2}$ & $\mathrm{CH}_{2}$ \\
\hline $\mathbf{7}$ & 109.6 & 119.2 & 125.2 & 125.9 & 140.9 & 120.3 & 142.1 & $74.6\left(\mathrm{t}, J_{\mathrm{CP}} 151\right)$ & \\
$\mathbf{9}$ & 110.2 & 120.0 & 121.1 & 126.7 & 141.7 & 122.6 & 140.3 & $72.1\left(\mathrm{t}, J_{\mathrm{CP}} 143\right)$ & 19.2 \\
\hline
\end{tabular}

\section{Conclusions}

We report the first synthesis of 1-hydroxy-1,1-indazolebisphosphonates substituted at N-1, N-2 and $\mathrm{C}-3$ positions of indazole ring, with the side chain with different $\left(\mathrm{CH}_{2}\right)_{\mathrm{n}}$ groups $(n=1-5$ for $\mathrm{N}-1$ and $\mathrm{N}-2$ isomers and $n=0,1$ for C-3 BPs), in moderated to good yields, starting from their corresponding carboxylic acids or acyl chlorides. In order to increase the synthetic yields, two different methods were used.

Despite the difficulty in the separation and purification of these bisphosphonates, they were fully characterized using the usual spectroscopic methods, especially NMR spectroscopy, including two dimensional NMR techniques. NMR spectroscopic characterization allowed the assignment of ${ }^{1} \mathrm{H}$ - and ${ }^{13} \mathrm{C}$ - atoms of different BPs. The presence of a quaternary carbon triplet 
confirmed the presence of the bisphosphonate group with two equivalent phosphorous atoms bonded to the same carbon atom.

This work also showed that NMR spectroscopy allowed the easy identification of the N-1, N2 and C-3 isomers since they showed spectra with different chemical shifts, especially the C-3, $\mathrm{C}-7$ and $\mathrm{C}-7 \mathrm{a}{ }^{13} \mathrm{C}$ NMR signals. The N-1 indazole BPs showed C-3 carbon atom generally shifted downfield $(\approx 10 \mathrm{ppm})$ relative to the corresponding carbon atom in N-2 indazole BPs, while C-7 and C-7a were shifted upfield. The C-7 and C-7a carbon atoms of C-3 substituted BPs (BPs 7 and 9) have similar chemical shifts relative to $\mathrm{N}-1$ isomers but the $\mathrm{C}-3$ quaternary carbon atom was observed further downfield, at approximately $8 \mathrm{ppm}$. Connectivities in HMBC spectra of BPs 7 and 9 also showed that those compounds present inversion in the chemical shift of C-3 and C-7a quaternary carbon atoms.

These synthesized BPs will be submitted to in vitro and in vivo studies to assess their potential therapeutic applications (studies currently in progress).

\section{Experimental Section}

General Procedures. NMR spectra were recorded on Bruker AMX 300 and on a Bruker Avance II $300\left({ }^{1} \mathrm{H} 300 \mathrm{MHz},{ }^{13} \mathrm{C}-75 \mathrm{MHz},{ }^{31} \mathrm{P} 121 \mathrm{MHz}\right)$ and on a Bruker Avance II $400\left({ }^{1} \mathrm{H} 400 \mathrm{MHz}\right.$, $\left.{ }^{13} \mathrm{C}-100 \mathrm{MHz},{ }^{31} \mathrm{P} 162 \mathrm{MHz}\right)$ spectrometers. Chemical shifts $(\delta)$ are reported in ppm and coupling constants $(J)$ in Hz. ${ }^{1} \mathrm{H}$ - and ${ }^{13} \mathrm{C}$ NMR chemical shifts were assigned using DEPT and APT sequences, and bidimensional COSY, HETCOR, HSQC and HMBC techniques. Assignments were made by comparison of chemical shifts, peak multiplicities and $J$ values, and were supported by bidimensional heteronuclear HMBC and HSQC correlation techniques. Infrared spectra were recorded on a Perkin Elmer FT-IR 1725xIR Fourier Transform spectrophotometer using $\mathrm{KBr}$ discs. The bands are quoted in $\mathrm{cm}^{-1}$. Low resolution and high resolution (HRMS) mass spectra analyses were performed at the 'C.A.C.T.I. - Unidad de Espectrometria de Masas' at the University of Vigo, Spain, on a VG AutoSpect M, MicroTOF (Bruker Daltonics) or APEX-Q (Bruker Daltonics) instrument. Elemental analysis were performed on a CE instrument EA 1110CHNS O and a Fisons EA-1108 elemental analyzer. Melting points were determined on a Reichert Thermovar melting point apparatus and are uncorrected.

All the reactions involving air sensitive reagents were performed under an atmosphere of dry nitrogen and all solvents were degassed before use. All solvents were distilled under a nitrogen atmosphere. THF were distilled from sodium benzophenone ketyl. $\mathrm{CHCl}_{3}$ was distilled from calcium hydride.

$1 H$-Indazole-3-carboxylic acid $\mathbf{6}$ is commercially available (Aldrich). Carboxylic acids 1a-e and 3a-e derived from indazole substituted at N-1 or N-2 position, with side chains with different lengths $(n=1-5)$, were prepared as already reported in the literature. ${ }^{18}$ Carboxylic acids 8 derived 
from indazole substituted at C-3 were synthesized in a two step synthesis according to reported synthetic procedures. ${ }^{22}$

\section{General procedure $1($ Method A)}

A mixture of a carboxylic acid (1 eq.), $\mathrm{H}_{3} \mathrm{PO}_{4}$ (85\%) (2 eq.) and chlorobenzene was heated to $100-110{ }^{\circ} \mathrm{C}$ with stirring. After all solids were dissolved, $\mathrm{PCl}_{3}$ (3 eq.) was added slowly and the reaction mixture was vigorously stirred at $100-110^{\circ} \mathrm{C}$ for $5 \mathrm{~h}$. After cooling, chlorobenzene was decanted and $9 \mathrm{~N} \mathrm{HCl}$ was added to the residue. The resulting solution was refluxed for $3 \mathrm{~h}$ and the solvent was removed under reduced pressure. Acetone and methanol were added to precipitate the 1-hydroxy-1,1-indazolebisphosphonate as a white powder, which was washed with acetone and dried.

\section{General procedure 2 (Method B)}

A mixture of a carboxylic acid (1 eq.) in $\mathrm{CHCl}_{3}$ and thionyl chloride (4 eq.) was kept under reflux for $2 \mathrm{~h}$. Solvents were removed under reduced pressure to give the corresponding acyl chloride, which was immediately used without further purification. The crude acyl chloride was dissolved in dry THF and tris(trimethylsilyl)phosphite (2 eq.) was added. Then, the mixture was stirred at room temperature for $30 \mathrm{~min}$. The excess solvent was removed under reduced pressure and methanol was added and the mixture was stirred for $1 \mathrm{~h}$. After solvent removal under reduced pressure, the residue was washed with ethyl ether and precipitated with acetone.

[1-Hydroxy-2-(1H-indazol-1-yl)ethane-1,1-diyl]bis(phosphonic acid) (2a). Following general procedure 1 (Method A), BP 2a was isolated as a white powder (16\%), mp 200-201 ${ }^{\circ} \mathrm{C}$. $v_{\max }$ $(\mathrm{KBr})\left(\mathrm{cm}^{-1}\right): 3567,3428,3152,3120,3014,2972,2794,1629,1519,1464,1433,1412,1383$, 1322, 1191, 1158, 1136, 1106, 1076, 1007, 963, 900, 863, 766, 758, 659, 608, 563, 540, 455. ${ }^{1} \mathrm{H}$ NMR $\left(300 \mathrm{MHz}, \mathrm{DMSO}-d_{6}\right): \delta(\mathrm{ppm})=4.85\left(2 \mathrm{H}, \mathrm{t}, J_{\mathrm{H}, \mathrm{P}} 10.2, \mathrm{NCH}_{2} \mathrm{C}(\mathrm{OH})\left(\mathrm{PO}_{3} \mathrm{H}_{2}\right)_{2}\right), 7.12$ $(1 \mathrm{H}, \mathrm{t}, J$ 7.2, $\mathrm{ArH}, 5-\mathrm{H}), 7.37(1 \mathrm{H}, \mathrm{dt}, J 7.2$ and 0.9, $\mathrm{ArH}, 6-\mathrm{H}), 7.61(1 \mathrm{H}, \mathrm{d}, J$ 8.1, ArH, 7-H), $7.74(1 \mathrm{H}, \mathrm{d}, J$ 8.1, $\mathrm{ArH}, 4-\mathrm{H}), 8.12(1 \mathrm{H}, \mathrm{d}, J 0.6,3-\mathrm{H}) .{ }^{13} \mathrm{C}$ NMR $\left(75 \mathrm{MHz}, \mathrm{DMSO}-d_{6}\right): \delta 50.0$ $\left(\mathrm{NCH}_{2}\right), 73.2$ (t, $J_{\mathrm{CP}}$ 143, C(OH) $\left.\left(\mathrm{PO}_{3} \mathrm{H}_{2}\right)_{2}\right), 110.8$ (Ar:C-7), 120.4 (Ar:C-5), 120.6 (Ar:C-4), 126.1 (Ar:C-6), 133.1 (Ar:C-3), 123.0 (Ar:C-3a), 140.4 (Ar:C-7a). ${ }^{31} \mathrm{P}$ NMR (121 MHz, $\mathrm{H}_{3} \mathrm{PO}_{4} /$ DMSO- $\left.d_{6}\right): \delta(\mathrm{ppm})=17.1$ MS $(\mathrm{FAB}) m / z: 323\left([\mathrm{M}+\mathrm{H}]^{+}\right), 305\left([\mathrm{M}+\mathrm{H}]^{+}-\mathrm{H}_{2} \mathrm{O}\right), 241\left([\mathrm{M}+\mathrm{H}]^{+}-\right.$ $\mathrm{H}_{3} \mathrm{PO}_{3}$ ). HRMS (FAB) Calcd for $\mathrm{C}_{9} \mathrm{H}_{13} \mathrm{~N}_{2} \mathrm{O}_{7} \mathrm{P}_{2} 323.0198$ : $[\mathrm{M}+\mathrm{H}]^{+}$, found 323.0205. Found: $\mathrm{C}$, 31.93, $\mathrm{H}, 4.16, \mathrm{~N}, 8.19 . \mathrm{C}_{9} \mathrm{H}_{12} \mathrm{~N}_{2} \mathrm{O}_{7} \mathrm{P}_{2}$. $\mathrm{H}_{2} \mathrm{O}$ requires: $\mathrm{C}, 31.78, \mathrm{H}, 4.15, \mathrm{~N}, 8.24 \%$.

[1-Hydroxy-3-(1H-indazol-1-yl)propane-1,1-diyl]bis(phosphonic acid) (2b). Following general procedure 1 (Method A), BP $2 \mathbf{b}$ was isolated as a white powder $(60 \%), \mathrm{mp} 127-130{ }^{\circ} \mathrm{C}$. $v_{\max }(\mathrm{KBr})\left(\mathrm{cm}^{-1}\right): 3534,3494,3417,3129,3044,2953,2922,2782,1645,1616,1504,1465$, $1431,1380,1368,1323,1278,1246,1231,1194,1172,1151,1073,1018,941,920,899,875$, $849,765,754,665,635,608,567,546,534,479,456 .{ }^{1} \mathrm{H}$ NMR (300 MHz, DMSO- $\left.d_{6}\right): \delta 2.35$ $\left(2 \mathrm{H}, \mathrm{m}, \mathrm{NCH}_{2} \mathrm{CH}_{2}\right), 4.67\left(2 \mathrm{H}, \mathrm{m}, \mathrm{NCH}_{2} \mathrm{CH}_{2}\right), 7.13(1 \mathrm{H}, \mathrm{t}, J 7.2, \mathrm{ArH}, 5-\mathrm{H}), 7.39(1 \mathrm{H}, \mathrm{t}, J$ 7.5, $\mathrm{ArH}, 6-\mathrm{H}), 7.61$ (1H, d, J 8.4, ArH, 7-H), 7.75 (1H, d, J 8.1, ArH, 4-H), 8.04 (1H, s, 3-H). ${ }^{13} \mathrm{C}$ NMR (75 MHz, DMSO-d $)$ : $\delta 33.6\left(\mathrm{NCH}_{2} \mathrm{CH}_{2}\right), 44.3\left(\mathrm{NCH}_{2} \mathrm{CH}_{2}\right), 71.2\left(\mathrm{t}, J_{\mathrm{CP}} 143\right.$, 
$\left.C(\mathrm{OH})\left(\mathrm{PO}_{3} \mathrm{H}_{2}\right)_{2}\right), 109.5$ (Ar:C-7), 120.4 (Ar:C-5), 121.0 (Ar:C-4), 126.0 (Ar:C-6), 132.6 (Ar:C3), 123.6 (Ar:C-3a), 138.8 (Ar:C-7a). ${ }^{31} \mathrm{P}$ NMR (121 MHz, $\left.\mathrm{H}_{3} \mathrm{PO}_{4} / \mathrm{DMSO}-d_{6}\right): \delta 19.8$. MS (FAB) $m / z: 337\left([\mathrm{M}+\mathrm{H}]^{+}\right), 255\left([\mathrm{M}+\mathrm{H}]^{+}-\mathrm{H}_{3} \mathrm{PO}_{3}\right)$. HRMS (FAB) Calcd for $\mathrm{C}_{10} \mathrm{H}_{15} \mathrm{~N}_{2} \mathrm{O}_{7} \mathrm{P}_{2}$ $337.0355[\mathrm{M}+\mathrm{H}]^{+}$. Found: $m / z$ 337.0367. Found: $\mathrm{C}, 33.83, \mathrm{H}, 4.58, \mathrm{~N}, 7.91 . \mathrm{C}_{10} \mathrm{H}_{14} \mathrm{~N}_{2} \mathrm{O}_{7} \mathrm{P}_{2} . \mathrm{H}_{2} \mathrm{O}$ requires: $\mathrm{C}, 33.91, \mathrm{H}, 4.55, \mathrm{~N}, 7.91 \%$.

[1-Hydroxy-4-(1H-indazol-1-yl)butane-1,1-diyl]bis(phosphonic acid) (2c). Following general procedure 1 (Method A), BP 2c was isolated as a white powder $(44 \%), m p 103-104{ }^{\circ} \mathrm{C}$. $v_{\max }$ $(\mathrm{KBr})\left(\mathrm{cm}^{-1}\right): 3400,3121,2946,1636,1459,1414,1390,1333,1192,1144,1114,1078,1001$, $951,861,846,765,670,656,590,563,540,516,485,435 .{ }^{1} \mathrm{H}$ NMR (300 MHz, DMSO- $\left.d_{6}\right): \delta$ $1.95\left(2 \mathrm{H}, \mathrm{m}, \mathrm{CH}_{2} \mathrm{C}(\mathrm{OH})\right), 2.10\left(2 \mathrm{H}, \mathrm{m}, \mathrm{NCH}_{2} \mathrm{CH}_{2}\right), 4.36\left(2 \mathrm{H}, \mathrm{t}, J 6,9, \mathrm{NCH}_{2} \mathrm{CH}_{2}\right), 7.11(1 \mathrm{H}, \mathrm{t}, J$ 7.2, $\mathrm{ArH}, 5-\mathrm{H}), 7.36(1 \mathrm{H}, \mathrm{dt}, J 7.5$ and 0.9, $\mathrm{ArH}, 6-\mathrm{H}), 7.63(1 \mathrm{H}, \mathrm{d}, J$ 8.4, $\mathrm{ArH}, 7-\mathrm{H}), 7.73(1 \mathrm{H}$, $\mathrm{d}, J 7.8, \mathrm{ArH}, 4-\mathrm{H}), 8.02(1 \mathrm{H}, \mathrm{d}, J 0.6,3-\mathrm{H}) .{ }^{13} \mathrm{C} \mathrm{NMR}\left(75 \mathrm{MHz}, \mathrm{DMSO}-d_{6}\right): \delta 24.3\left(\mathrm{NCH}_{2} \mathrm{CH}_{2}\right)$, $30.6\left(\mathrm{CH}_{2} \mathrm{C}(\mathrm{OH})\right), 49.0\left(\mathrm{NCH}_{2} \mathrm{CH}_{2}\right), 72.2\left(\mathrm{t}, J_{\mathrm{CP}} 143, \mathrm{C}(\mathrm{OH})\left(\mathrm{PO}_{3} \mathrm{H}_{2}\right)_{2}\right), 109.8$ (Ar:C-7), 120.3 (Ar:C-5), 120.9 (Ar:C-4), 125.9 (Ar:C-6), 132.3 (Ar:C-3), 123.5 (Ar:C-3a), 139.1 (Ar:C-7a). ${ }^{31} \mathrm{P}$ NMR $\left(121 \mathrm{MHz}, \mathrm{H}_{3} \mathrm{PO}_{4} / \mathrm{DMSO}-d_{6}\right): \delta(\mathrm{ppm})=20.6$. MS (FAB) $m / z: 351\left([\mathrm{M}+\mathrm{H}]^{+}\right), 333$ $\left([\mathrm{M}+\mathrm{H}]^{+}-\mathrm{H}_{2} \mathrm{O}\right), 269\left([\mathrm{M}+\mathrm{H}]^{+}-\mathrm{H}_{3} \mathrm{PO}_{3}\right)$. HRMS (FAB) Calcd for $\mathrm{C}_{11} \mathrm{H}_{17} \mathrm{~N}_{2} \mathrm{O}_{7} \mathrm{P}_{2} 351.0511$. $[\mathrm{M}+\mathrm{H}]^{+}$. Found: $m / z 351.0514$.

[1-Hydroxy-5-(1H-indazol-1-yl)pentane-1,1-diyl]bis(phosphonic acid) (2d). Following general procedure 1 (Method A), the BP 2d was isolated as a white powder (62\%), mp 128-130 ${ }^{\circ} \mathrm{C}$. $v_{\max }(\mathrm{KBr}): 3291,3138,2967,2924,2855,2759,1634,1522,1466,1385,1323,1262,1190$, 1162, 1142, 1084, 1053, 1004, 965, 891, 759, 669, 530, 469, 430 $\mathrm{cm}^{-1}$. ${ }^{1} \mathrm{H}$ NMR (300 MHz, MeOD-d $\left.)_{4}\right): \delta 1.77\left(2 \mathrm{H}, \mathrm{m}, \mathrm{CH}_{2}\right), 1.89\left(2 \mathrm{H}, \mathrm{m}, \mathrm{CH}_{2}\right), 2.12\left(2 \mathrm{H}, \mathrm{m}, \mathrm{CH}_{2}\right), 4.42(2 \mathrm{H}, \mathrm{t}, J$ 7.2, $\left.\mathrm{NCH}_{2} \mathrm{CH}_{2}\right), 7.13(1 \mathrm{H}, \mathrm{m}, \mathrm{ArH}, 5-\mathrm{H}), 7.40(1 \mathrm{H}, \mathrm{m}, \mathrm{ArH}, 6-\mathrm{H}), 7.55(1 \mathrm{H}, \mathrm{dd}, J 8.7$ and 0.9, $\mathrm{ArH}$, 7-H), $7.73\left(1 \mathrm{H}, \mathrm{d}, J\right.$ 8.1, ArH, 4-H), $7.99(1 \mathrm{H}, \mathrm{d}, J 0.6,3-\mathrm{H}) .{ }^{13} \mathrm{C}$ NMR $\left(75 \mathrm{MHz}, \mathrm{MeOD}-d_{4}\right): \delta$ 22.2, 31.7, $34.6\left(\mathrm{CH}_{2}\right), 49.5\left(\mathrm{NCH}_{2} \mathrm{CH}_{2}\right), 74.2$ (t, $\left.J_{\mathrm{CP}} 146, C(\mathrm{OH})\left(\mathrm{PO}_{3} \mathrm{H}_{2}\right)_{2}\right), 110.5(\mathrm{Ar}: \mathrm{C}-7)$, 121.9, 122.2 (Ar:C-4,C-5), 127.9 (Ar:C-6), 133.7 (Ar:C-3), 125.1 (Ar:C-3a), 140.7 (Ar:C-7a). ${ }^{31} \mathrm{P}$ NMR (121 MHz, $\left.\mathrm{H}_{3} \mathrm{PO}_{4} / \mathrm{MeOD}-d_{4}\right): \delta$ 19.5. MS (FAB) $m / z: 365\left([\mathrm{M}+\mathrm{H}]^{+}\right), 347\left([\mathrm{M}+\mathrm{H}]^{+}-\right.$ $\left.\mathrm{H}_{2} \mathrm{O}\right), 283\left([\mathrm{M}+\mathrm{H}]^{+}-\mathrm{H}_{3} \mathrm{PO}_{3}\right)$. HRMS (FAB) $m / z$ Calcd for $\mathrm{C}_{12} \mathrm{H}_{19} \mathrm{~N}_{2} \mathrm{O}_{7} \mathrm{P}_{2} 365.0668[\mathrm{M}+\mathrm{H}]^{+}$, found 365.0674 .

[1-Hydroxy-6-(1H-indazol-1-yl)hexane-1,1-diyl]bis(phosphonic acid) (2e). Following general procedure 1 (Method A), BP 2e was isolated as a white powder (50\%). mp 118-120 ${ }^{\circ} \mathrm{C} . v_{\max }$ (KBr) 3377, 3128, 2942, 2866, 1631, 1466, 1384, 1367, 1171, 1139, 1092, 1007, 947, 838, 754, $670,662,514 \mathrm{~cm}^{-1} .{ }^{1} \mathrm{H}$ NMR $\left(300 \mathrm{MHz}, \mathrm{MeOD}-d_{4}\right): \delta(\mathrm{ppm})=1.28\left(2 \mathrm{H}, \mathrm{m}, \mathrm{CH}_{2}\right), 1.73(2 \mathrm{H}, \mathrm{m}$, $\left.\mathrm{CH}_{2}\right), 1.90\left(4 \mathrm{H}, \mathrm{m}, \mathrm{CH}_{2}\right), 4.42\left(2 \mathrm{H}, \mathrm{t}, J 6.9, \mathrm{NCH}_{2} \mathrm{CH}_{2}\right), 7.14(1 \mathrm{H}, \mathrm{t}, J 7.8, \mathrm{ArH}, 5-\mathrm{H}), 7.41(1 \mathrm{H}$, m, ArH, 6-H), 7.57 (1H, d, J 8.4, ArH, 7-H), 7.74 (1H, d, J 8.4, ArH, 4-H), 8.01 (1H, s, 3-H). ${ }^{13} \mathrm{C} \mathrm{NMR}\left(75 \mathrm{MHz}, \mathrm{MeOD}-d_{4}\right): \delta(\mathrm{ppm})=24.1,28.4,30.7,35.0\left(\mathrm{CH}_{2}\right), 49.4\left(\mathrm{NCH}_{2} \mathrm{CH}_{2}\right), 74.3$ $\left(\mathrm{t}, J_{\mathrm{CP}} 146, C(\mathrm{OH})\left(\mathrm{PO}_{3} \mathrm{H}_{2}\right)_{2}\right), 110.5$ (Ar:C-7), 121.9, 122.2 (Ar:C-4, C-5), 128.0 (Ar:C-6), 133.7 (Ar:C-3), 124.9 (Ar:C-3a), 140.9 (Ar:C-7a). ${ }^{31} \mathrm{P}$ NMR (121 MHz, $\left.\mathrm{H}_{3} \mathrm{PO}_{4} / \mathrm{MeOD}_{4}\right): \delta(\mathrm{ppm})=$ 21.1. MS (FAB) $m / z: 379\left([\mathrm{M}+\mathrm{H}]^{+}\right), 297\left([\mathrm{M}+\mathrm{H}]^{+}-\mathrm{H}_{3} \mathrm{PO}_{3}\right)$. HRMS (FAB) $m / z$ Calcd for $\mathrm{C}_{13} \mathrm{H}_{21} \mathrm{~N}_{2} \mathrm{O}_{7} \mathrm{P}_{2} 379.0824[\mathrm{M}+\mathrm{H}]^{+}$; found 379.0808 . 
[1-Hydroxy-2-(2H-indazol-2-yl)ethane-1,1-diyl]bis(phosphonic acid) (5a). Using general procedure 1 (Method A), compound 5a was isolated as a white powder $(6 \%), \mathrm{mp} 181^{\circ} \mathrm{C}$ (decomp.), $v_{\max }(\mathrm{KBr}) 3445,2922,2856,1645,1456,1199,1140,1078,1011,945,853,752 \mathrm{~cm}^{-}$ 1. ${ }^{1} \mathrm{H}$ NMR $\left(300 \mathrm{MHz}, \mathrm{DMSO}-d_{6}\right): \delta 4.90\left(2 \mathrm{H}, \mathrm{t}, J_{\mathrm{HP}} 10.5, \mathrm{NCH}_{2} \mathrm{C}(\mathrm{OH})\left(\mathrm{PO}_{3} \mathrm{H}_{2}\right)_{2}\right), 7.04(1 \mathrm{H}, \mathrm{t}, J$ 8.1, $\operatorname{Ar} H), 7.27(1 \mathrm{H}, \mathrm{t}, J$ 8.4, $\operatorname{ArH}), 7.58(1 \mathrm{H}, \mathrm{d}, J 8.7, \operatorname{Ar} H), 7.72(1 \mathrm{H}, \mathrm{d}, J 8.4, \operatorname{Ar} H), 8.42(1 \mathrm{H}$, s, 3-H). ${ }^{13} \mathrm{C}$ NMR (75 MHz, DMSO-d 6 ): $\delta 55.0\left(\mathrm{NCH}_{2}\right), 73.0\left(\mathrm{t}, J_{\mathrm{CP}} 141, C(\mathrm{OH})\left(\mathrm{PO}_{3} \mathrm{H}_{2}\right)_{2}\right), 116.6$ (Ar:C-7), 121.3, 121.5 (Ar:C-4, C-5), 127.6 (Ar:C-6), 126.8 (Ar:C-3), 121.2 (Ar:C-3a), 147.8 (Ar:C-7a). ${ }^{31} \mathrm{P}$ NMR (121 MHz, $\left.\mathrm{H}_{3} \mathrm{PO}_{4} / \mathrm{DMSO}-d_{6}\right): \delta 16.5$. MS (FAB) $m / z: 323\left([\mathrm{M}+\mathrm{H}]^{+}\right), 241$ $\left([\mathrm{M}+\mathrm{H}]^{+}-\mathrm{H}_{3} \mathrm{PO}_{3}\right)$. HRMS (FAB) $\mathrm{m} / z$ Calcd for $\mathrm{C}_{9} \mathrm{H}_{13} \mathrm{~N}_{2} \mathrm{O}_{7} \mathrm{P}_{2} 323.0198[\mathrm{M}+\mathrm{H}]^{+}$. Found: 323.0193 .

[1-Hydroxy-3-(2H-indazol-2-yl)propane-1,1-diyl]bis(phosphonic acid) (5b). Following general procedure 2 (Method B), compound 5b was isolated as a white powder (77\%). mp 198$200{ }^{\circ} \mathrm{C}$. $v_{\max }(\mathrm{KBr}): 3432,3294,3109,2894,2618,2553,1639,1528,1432,1390,1370,1246$, $1217,1168,1149,1133,1054,1013,989,945,926,879,772,762,719,652,611,536,470 \mathrm{~cm}^{-1}$. ${ }^{1} \mathrm{H}$ NMR (300 MHz, DMSO-d $): \delta 2.49\left(2 \mathrm{H}, \mathrm{m}, \mathrm{NCH}_{2} \mathrm{CH}_{2}\right), 4.67\left(2 \mathrm{H}, \mathrm{m}, \mathrm{NCH}_{2} \mathrm{CH}_{2}\right), 7.02(1 \mathrm{H}$, t, $J$ 8.1, ArH, 5-H), $7.22(1 \mathrm{H}, \mathrm{t}, J$ 8.4, $\mathrm{ArH}, 6-\mathrm{H}), 7.58(1 \mathrm{H}, \mathrm{d}, J$ 8.7, $\mathrm{ArH}, 7-\mathrm{H}), 7.68(1 \mathrm{H}, \mathrm{d}, J$ 8.4, $\mathrm{ArH}, 4-\mathrm{H}), 8.30(1 \mathrm{H}, \mathrm{s}, 3-\mathrm{H}) .{ }^{13} \mathrm{C} \mathrm{NMR}\left(75 \mathrm{MHz}, \mathrm{DMSO}-d_{6}\right): \delta 34.6\left(\mathrm{NCH}_{2} \mathrm{CH}_{2}\right), 48.8$ $\left(\mathrm{NCH}_{2} \mathrm{CH}_{2}\right), 71.1$ (t, $J_{\mathrm{CP}}$ 143, $\left.C(\mathrm{OH})\left(\mathrm{PO}_{3} \mathrm{H}_{2}\right)_{2}\right), 116.8$ (Ar:C-7), 120.6 (Ar:C-4), 120.9 (Ar:C-5), 123.5 (Ar:C-3), 125.4 (Ar:C-6), 121.4 (Ar:C-3a), 147.9 (Ar:C-7a). ${ }^{31} \mathrm{P}$ NMR (121 MHz, $\mathrm{H}_{3} \mathrm{PO}_{4}$ : DMSO- $\left.d_{6}\right): \delta$ 19.5. MS (FAB) $m / z: 337\left([\mathrm{M}+\mathrm{H}]^{+}\right), 255\left([\mathrm{M}+\mathrm{H}]^{+}-\mathrm{H}_{3} \mathrm{PO}_{3}\right)$. HRMS (FAB) Calcd for $\mathrm{C}_{10} \mathrm{H}_{15} \mathrm{~N}_{2} \mathrm{O}_{7} \mathrm{P}_{2} 337.0355[\mathrm{M}+\mathrm{H}]^{+}$, found 337.0370. Found: $\mathrm{C}, 32.41, \mathrm{H}, 5.02, \mathrm{~N}, 7.40$. $\mathrm{C}_{10} \mathrm{H}_{14} \mathrm{~N}_{2} \mathrm{O}_{7} \mathrm{P}_{2}$. $2 \mathrm{H}_{2} \mathrm{O}$ requires $\mathrm{C}, 32.27, \mathrm{H}, 4.87, \mathrm{~N}, 7.53 \%$.

[1-Hydroxy-4-(2H-indazol-2-yl)butane-1,1-diyl]bis(phosphonic acid) (5c). Following general procedure 1 (Method A) and the general procedure 2 (Method B), 5c was isolated as a white powder $(17 \%), \operatorname{mp~} 174-175^{\circ} \mathrm{C}$. $v_{\max }(\mathrm{KBr})\left(\mathrm{cm}^{-1}\right): 3421,3220,3132,2958,2928,2781,1637$, 1529, 1388, 1369, 1216, 1185, 1162, 1003, 990, 945, 760, 670, 648, 633, 613, 525, 510, 467. ${ }^{1} \mathrm{H}$ NMR $\left(300 \mathrm{MHz}, \mathrm{DMSO}-d_{6}\right): \delta 1.90\left(2 \mathrm{H}, \mathrm{m}, \mathrm{CH}_{2} \mathrm{C}(\mathrm{OH})\right), 2.20\left(2 \mathrm{H}, \mathrm{m}, \mathrm{NCH}_{2} \mathrm{CH}_{2}\right), 4.38(2 \mathrm{H}$, m, $\left.\mathrm{NCH}_{2} \mathrm{CH}_{2}\right), 7.01(1 \mathrm{H}, \mathrm{t}, J$ 7.5, $\mathrm{ArH}, 5-\mathrm{H}), 7.21(1 \mathrm{H}, \mathrm{t}, J$ 8.7, $\mathrm{ArH}, 6-\mathrm{H}), 7.57(1 \mathrm{H}, \mathrm{d}, J$ 8.7, $\mathrm{ArH}, 7-\mathrm{H}), 7.68(1 \mathrm{H}, \mathrm{d}, J$ 8.4, $\mathrm{ArH}, 4-\mathrm{H}), 8.30(1 \mathrm{H}, \mathrm{s}, 3-\mathrm{H}) .{ }^{13} \mathrm{C}$ NMR $\left(75 \mathrm{MHz}, \mathrm{DMSO}-d_{6}\right): \delta$ $25.2\left(\mathrm{NCH}_{2} \mathrm{CH}_{2}\right), 30.5\left(\mathrm{CH}_{2} \mathrm{C}(\mathrm{OH})\right), 53.7\left(\mathrm{NCH}_{2}\right), 72.3\left(\mathrm{t}, J_{\mathrm{CP}} 142, C(\mathrm{OH})\left(\mathrm{PO}_{3} \mathrm{H}_{2}\right)_{2}\right), 117.1$ (Ar:C-7), 120.9 (Ar:C-4), 121.6 (Ar:C-5), 123.9 (Ar:C-3), 125.7 (Ar:C-6), 121.2 (Ar:C-3a), 148.1 (Ar:C-7a). ${ }^{31} \mathrm{P}$ NMR (121 MHz H$\left.{ }_{3} \mathrm{PO}_{4} / \mathrm{DMSO}-d_{6}\right): \delta 20.3$. MS (FAB) $m / z: 351\left([\mathrm{M}+\mathrm{H}]^{+}\right)$, $269\left([\mathrm{M}+\mathrm{H}]^{+}-\mathrm{H}_{3} \mathrm{PO}_{3}\right)$. HRMS (FAB) Calcd for $\mathrm{C}_{11} \mathrm{H}_{17} \mathrm{~N}_{2} \mathrm{O}_{7} \mathrm{P}_{2}$ 351.0511. [M+H] $]^{+}$. Found: $\mathrm{m} / z$ 351.0515 .

[1-Hydroxy-5-(2H-indazol-2-yl)pentane-1,1-diyl]bis(phosphonic acid) (5d). Following general procedure 1 (Method A), BP 5d was isolated as a white powder (39\%). mp 202-203 ${ }^{\circ} \mathrm{C}$. $v_{\max }(\mathrm{KBr})\left(\mathrm{cm}^{-1}\right): 3398,3199,3016,2958,2853,2685,1638,1528,1388,1364,1241,1172$, 1148, 1127, 1108, 1088, 1030, 996, 973, 930, 900, 828, 757, 744, 638, 610, 530, 520, 488, 478, 468, 449. ${ }^{1} \mathrm{H}$ NMR (300 MHz, DMSO- $\left.d_{6}\right): \delta 1.60\left(2 \mathrm{H}, \mathrm{m}, \mathrm{CH}_{2}\right), 1.84\left(4 \mathrm{H}, \mathrm{m}, \mathrm{CH}_{2} \mathrm{CH}_{2}\right), 4.35$ $\left(2 \mathrm{H}, \mathrm{m}, \mathrm{NCH}_{2} \mathrm{CH}_{2}\right), 7.01(1 \mathrm{H}, \mathrm{t}, J$ 7.5, $\mathrm{ArH}, 5-\mathrm{H}), 7.21(1 \mathrm{H}, \mathrm{t}, J$ 8.4, $\mathrm{ArH}, 6-\mathrm{H}), 7.57(1 \mathrm{H}, \mathrm{d}, J$ 
8.7, $\mathrm{ArH}, 7-\mathrm{H}), 7.67(1 \mathrm{H}, \mathrm{d}, J 8.4, \mathrm{Ar} H, 4-\mathrm{H}), 8.33(1 \mathrm{H}, \mathrm{s}, 3-\mathrm{H}) .{ }^{13} \mathrm{C}$ NMR $\left(75 \mathrm{MHz}, \mathrm{DMSO}-d_{6}\right)$ : $\delta$ 20.5, 31.1, $33.0\left(\mathrm{CH}_{2}\right), 52.9\left(\mathrm{NCH}_{2} \mathrm{CH}_{2}\right), 72.4\left(\mathrm{t}, J_{\mathrm{CP}} 143, C(\mathrm{OH})\left(\mathrm{PO}_{3} \mathrm{H}_{2}\right)_{2}\right), 117.0(\mathrm{Ar}: \mathrm{C}-7)$, 120.7 (Ar:C-4), 121.4 (Ar:C-5), 123.8 (Ar:C-3), 125.4 (Ar:C-6), 121.0 (Ar:C-3a), 148.0 (Ar:C7a). ${ }^{31} \mathrm{P}$ NMR (121 MHz, $\left.\mathrm{H}_{3} \mathrm{PO}_{4} / \mathrm{DMSO}_{-} d_{6}\right): \delta$ 21.0. MS (FAB) $\mathrm{m} / z: 365\left([\mathrm{M}+\mathrm{H}]^{+}\right)$. HRMS (FAB) $m / z$ Calcd for $\mathrm{C}_{12} \mathrm{H}_{19} \mathrm{~N}_{2} \mathrm{O}_{7} \mathrm{P}_{2} 365.0668[\mathrm{M}+\mathrm{H}]^{+}$. Found: $m / z$ 365.0672.

[1-Hydroxy-6-(2H-indazol-2-yl)hexane-1,1-diyl]bis(phosphonic acid) (5e). Following general procedure 1 (Method A), BP 5e was isolated as a white powder $(87 \%)$, mp 144-145 ${ }^{\circ} \mathrm{C} . v_{\max }$ (KBr) $\left(\mathrm{cm}^{-1}\right): 3367,3126,3108,2929,2861,2764,2695,1637,1528,1466,1458,1388,1367$, $1165,1146,1062,1002,939,757,668,662,612,569,519 .{ }^{1} \mathrm{H}$ NMR (300 MHz, DMSO- $\left.d_{6}\right): \delta$ $1.15\left(2 \mathrm{H}, \mathrm{m}, \mathrm{CH}_{2}\right), 1.59\left(2 \mathrm{H}, \mathrm{m}, \mathrm{CH}_{2}\right), 1.86\left(4 \mathrm{H}, \mathrm{m}, \mathrm{CH}_{2}\right), 4.39\left(2 \mathrm{H}, \mathrm{m}, \mathrm{NCH}_{2} \mathrm{CH}_{2}\right), 7.01(1 \mathrm{H}, \mathrm{t}$, $J 7.5, \mathrm{ArH}, 5-\mathrm{H}), 7.21(1 \mathrm{H}, \mathrm{t}, J 8.1, \mathrm{Ar} H, 6-\mathrm{H}), 7.58(1 \mathrm{H}, \mathrm{d}, J 8.4, \operatorname{Ar} H, 7-\mathrm{H}), 7.67(1 \mathrm{H}, \mathrm{d}, J 8.4$, $\mathrm{ArH}, 4-\mathrm{H}), 8.34(1 \mathrm{H}, \mathrm{s}, 3-\mathrm{H}) .{ }^{13} \mathrm{C}$ NMR $\left(75 \mathrm{MHz}, \mathrm{DMSO}-d_{6}\right): \delta 22.6,26.9,30.1,33.3\left(\mathrm{CH}_{2}\right)$, $52.8\left(\mathrm{NCH}_{2} \mathrm{CH}_{2}\right), 72.5$ (t, $\left.J_{\mathrm{CP}} 143, C(\mathrm{OH})\left(\mathrm{PO}_{3} \mathrm{H}_{2}\right)_{2}\right), 116.9$ (Ar:C-7), 120.7 (Ar:C-4), 121.0 (Ar:C-5), 124.0 (Ar:C-3), 125.5 (Ar:C-6), 121.4 (Ar:C-3a), 147.9 (Ar:C-7a). ${ }^{31} \mathrm{P}$ NMR (121 $\left.\mathrm{MHz}, \mathrm{H}_{3} \mathrm{PO}_{4} / \mathrm{DMSO}_{-} d_{6}\right): \delta$ 21.1. MS (FAB) $\mathrm{m} / z: 379\left([\mathrm{M}+\mathrm{H}]^{+}\right), 297\left([\mathrm{M}+\mathrm{H}]^{+}-\mathrm{H}_{3} \mathrm{PO}_{3}\right)$. HRMS (FAB) Calcd for $\mathrm{C}_{13} \mathrm{H}_{21} \mathrm{~N}_{2} \mathrm{O}_{7} \mathrm{P}_{2}, 379.0824[\mathrm{M}+\mathrm{H}]^{+}$. Found: $m / z$ 379.0829. Found: C, 38.68, H, 5.70, N, 6.80. $\mathrm{C}_{13} \mathrm{H}_{20} \mathrm{~N}_{2} \mathrm{O}_{7} \mathrm{P}_{2}$. $4 / 3 \mathrm{H}_{2} \mathrm{O}$ requires: $\mathrm{C}, 38.81, \mathrm{H}, 5.68, \mathrm{~N}, 6.96 \%$.

[Hydroxy(1H-indazol-3-yl)methanediyl]bis(phosphonic acid) (7). Following general procedure 2 (Method B), BP 7 was isolated as a white powder (67\%), mp 203-205 ${ }^{\circ} \mathrm{C}$ (decomp.). $v_{\max }(\mathrm{KBr})\left(\mathrm{cm}^{-1}\right): 3555,3408,3257,3061,2998,2940,2766,2701,1636,1560,1522,1456$, 1399, 1358, 1241, 1170, 1086, 1020, 954, 918, 894, 882, 807, 767, 747, 663, 586, 525, 487, 445. ${ }^{1} \mathrm{H}$ NMR (300 MHz, DMSO- $\left.d_{6}\right): \delta 7.01(1 \mathrm{H}, \mathrm{t}, J 7.5, \operatorname{Ar} H, 5-\mathrm{H}), 7.30(1 \mathrm{H}, \mathrm{t}, J$ 8.1, $\operatorname{Ar} H, 6-\mathrm{H})$, $7.45(1 \mathrm{H}, \mathrm{d}, J$ 8.4 $\mathrm{ArH}, 7-\mathrm{H}), 8.28(1 \mathrm{H}, \mathrm{d}, J 8.1, \mathrm{Ar} H, 4-\mathrm{H}) .{ }^{13} \mathrm{C}$ NMR (75 MHz, DMSO- $\left.d_{6}\right): \delta$ $74.6\left(\mathrm{t}, J_{\mathrm{CP}} 151, C(\mathrm{OH})\left(\mathrm{PO}_{3} \mathrm{H}_{2}\right)_{2}\right), 109.6$ (Ar:C-7), 119.2 (Ar:C-5), 125.2 (Ar:C-4), 125.9 (Ar:C6), 120.3 (Ar:C-3a), 140.9 (Ar:C-3), 142.1 (Ar:C-7a). ${ }^{31} \mathrm{P} \mathrm{NMR} \mathrm{(121} \mathrm{MHz,} \mathrm{H}_{3} \mathrm{PO}_{4} / \mathrm{DMSO}_{6}$ ): $\delta$ 15.4. MS (FAB) $m / z: 309\left([\mathrm{M}+\mathrm{H}]^{+}\right), 227\left([\mathrm{M}+\mathrm{H}]^{+}-\mathrm{H}_{3} \mathrm{PO}_{3}\right)$. HRMS (FAB) Calcd for $\mathrm{C}_{8} \mathrm{H}_{11} \mathrm{~N}_{2} \mathrm{O}_{7} \mathrm{P}_{2} 309.0042[\mathrm{M}+\mathrm{H}]^{+}$, found 309.0037. Found: C, 28.26, H, 4.24, N, 8.12. $\mathrm{C}_{8} \mathrm{H}_{10} \mathrm{~N}_{2} \mathrm{O}_{7} \mathrm{P}_{2} .2 \mathrm{H}_{2} \mathrm{O}$ requires: $\mathrm{C}, 27.92, \mathrm{H}, 4.10, \mathrm{~N}, 8.14 \%$.

[1-Hydroxy-2-(1H-indazol-3-yl)ethane-1,1-diyl]bis(phosphonic acid) (9). Using the general procedure 2, Method B, BP 9 was isolated as a white powder (16\%), mp 200-202 ${ }^{\circ} \mathrm{C}$ (decomp.). $v_{\max }(\mathrm{KBr})\left(\mathrm{cm}^{-1}\right): 3448,3204,2997,2926,2864,2744,1638,1420,1388,1358,1220,1154$, 1142, 1082, 1061, 1008, 925, 897, 843, 779, 757, 698, 536, 504, 468. ${ }^{1} \mathrm{H}$ NMR (300 MHz, DMSO- $\left.d_{6}\right): \delta 3.57\left(2 \mathrm{H}, \mathrm{t}, J_{\mathrm{HP}} 13.5, \mathrm{NCH}_{2} \mathrm{C}(\mathrm{OH})\left(\mathrm{PO}_{3} \mathrm{H}_{2}\right)_{2}\right), 7.08(1 \mathrm{H}, \mathrm{t}, J 7.8, \mathrm{Ar} H, 5-\mathrm{H}), 7.35$ $(1 \mathrm{H}, \mathrm{t}, J$ 8.1, $\mathrm{ArH}, 6-\mathrm{H}), 7.48(1 \mathrm{H}, \mathrm{d}, J 8.4, \operatorname{Ar} H, 7-\mathrm{H}), 7.77(1 \mathrm{H}, \mathrm{d}, J 8.1, \mathrm{ArH}, 4-\mathrm{H}) .{ }^{13} \mathrm{C} \mathrm{NMR}$ (75 MHz, DMSO- $\left.d_{6}\right): \delta 29.0\left(\mathrm{NCH}_{2} \mathrm{C}(\mathrm{OH})\left(\mathrm{PO}_{3} \mathrm{H}_{2}\right)_{2}\right), 72.1\left(\mathrm{t}, J_{\mathrm{CP}} 143, C(\mathrm{OH})\left(\mathrm{PO}_{3} \mathrm{H}_{2}\right)_{2}\right), 110.2$ (Ar:C-7), 120.0 (Ar:C-5), 121.1 (Ar:C-4), 126.7 (Ar:C-6), 122.6 (Ar:C-3a), 140.3 (Ar:C-7a), 141.7 (Ar:C-3). ${ }^{31} \mathrm{P}$ NMR (121 MHz, $\left.\mathrm{H}_{3} \mathrm{PO}_{4} / \mathrm{DMSO}-d_{6}\right): \delta$ 19.2. MS (ESI) $m / z: 323\left([\mathrm{M}+\mathrm{H}]^{+}\right)$. HRMS (ESI) Calcd for $\mathrm{C}_{9} \mathrm{H}_{13} \mathrm{~N}_{2} \mathrm{O}_{7} \mathrm{P}_{2}: 323.0193[\mathrm{M}+\mathrm{H}]^{+}$. Found: $m / z, 323.0205$. 


\section{Acknowledgements}

We thank Fundação para a Ciência e a Tecnologia (POCTI and FEDER programs) for funding (Projects POCTI/39368/QUI/2001 and POCI/QUI/55508/2004). APST thanks the Portuguese NMR Network (IST-UTL Center) for access to the NMR facility.

\section{References}

1. (a) Russel, R. G.; Rogers, M. J. Bone 1999, 25, 97. (b) Fleisch, H. In Bisphosphonates in Bone Disease - From the Laboratory to the Patient, $4^{\text {th }}$ Ed., Academic Press: San Diego, 2000. (c) Fleisch, H. Breast Cancer Res. 2002, 4, 30. (d) Zhang, S.; Gangal, G.; Uluda, H. Chem. Soc. Rev. 2007, 36, 507.

2. Green, J. R. J. Organomet. Chem. 2005, 690, 2439.

3. Van Beek, E. R.; Löwik, C. W. G. M.; Ebetino, F. H.; Papapoulos, S. E. Bone 1998, 23, 437.

4. (a) Fleich, H. Endocrine Reviews 1998, 19, 80. (b) Rogers, M. J.; Frith, J. C.; Luckman, S. P.; Coxon, F. P.; Benford, H. L.; Monkkonen, J.; Auriola, S.; Chilton, K. M.; Russel, R. G. G. Bone 1999, 24, 73S.

5. Hodsman, A.; Adachi, J.; Olszynski, W. Can. Med. Assoc. J. 1996, 155, 945.

6. (a) Paterson, A. H. G.; Powles, T. J.; Kanis, J. A.; McCloskey, E.; Hanson, J.; Ashley, S. J. Clin. Oncol. 1993, 11, 59. (b) Hortobagyi, G. N.; Theriault, R. L.; Porter, L.; Blayney, D.; Lipton, A.; Sinoff, C.; Wheeler, H.; Simeone, J. F.; Seaman, J.; Knight, R. D. N. Engl. J. Med. 1996, 335, 1785. (c) Diel, I. J.; Solomayer, E. F.; Costa, S. D.; Gollan, C.; Goerner, R.; Wallwiener, D.; Kaufmann, M.; Bastert, G. N. Engl. J. Med. 1998, 339, 357. (d) Theriault, R. L.; Lipton, A.; Hortobagyi, G. N.; Leff, R.; Gluck, S.; Stewart, J. F.; Costello, S.; Kennedy, I.; Simeone, J.; Seaman, J. J.; Knight, R. D.; Mellars, K.; Heffernan, M.; Reitsma, D. J. J. Clin. Oncol. 1999, 17, 846.

7. (a) Sasaki, A.; Boyce, B. F.; Story, B.; Wright, K. R.; Chapman, M.; Boyce, R.; Mundy, G. R.; Yoneda, T. Cancer Res. 1995, 55, 3551. (b) Sasaki, A.; Kitamura, K.; Alcalde, R. E.; Tanaka, T.; Suzuki, A.; Etoh, Y.; Matsumura, T. Int. J. Cancer 1998, 77, 279.

8. (a) Boissier, S.; Ferreras, M.; Peyruchaud, O.; Magnetto, S.; Ebetino, F. H.; Colombel, M.; Delmas, P.; Delaisse, J. -M.; Clezardin, P. Cancer Res. 2000, 60, 2949. (b) Virtanen, S.; Väänänen, H. K.; Härkönen, P. L.; Lakkakorpi, P. T. Cancer Res. 2002, 62, 2708. (c) van der Pluijm, G.; Vloedgraven, H.; van Beek, E.; van der Wee-Pals, L.; Lowik, C.; Papapoulos, S. J. Clin. Invest. 1996, 98, 698. (d) Boissier, S.; Magnetto, S.; Frappart, L.; Cuzin, B.; Ebetino, F. H.; Delmas, P. D.; Clezardin, P. Cancer Res. 1997, 57, 3890.

9. Fournier, P.; Boissier, S.; Filleur, S.; Guglielmi, J.; Cabon, F.; Colombel, M.; Clézardin, P. Cancer 2002, 62, 6538.

10. Schlachter, S. T.; Galinet, L. A.; Shields, S. K.; Aspar, D. G.; Dunn, C. J.; Staite, N. D.; Nugent, R. A. Bioorganic Med. Chem. Lett. 1998, 8, 1093. 
11. Volkert, W. A.; Hoffman, T. J. Chem. Rev. 1999, 99, 2269. (b) Allen Jr., A.; Manke, D. R.; Lin, W. Tetrahedron Lett. 2000, 41, 151. (c) Handy, N. A. T.; Papapoulos, S. E. Seminars in Nuclear Medicine 2001, XXXI, 62.

12. (a) Kontecka, E. G.; Jezierska, J.; Lecouvey, M.; Leroux, Y.; Kozlowski, H. J. Inorg. Biochem. 2002, 89, 13. (b) Dyba, M.; Kozlowski, H.; Tlalka, A.; Leroux, Y.; Manouni, D. El Pol. J. Chem. 1998, 72, 1148. (c) Kontecka, E. G.; Silvagni, R.; Lipinski, R.; Lecouvey, M.; Marincola, F. C.; Crisponi, G.; Nurchi, V. M.; Leroux, Y.; Kozlowski, H. Inorg. Chim. Acta 2002, 339, 111. (d) Matczak-Jon, E.; Kurzak, B.; Kamecka, A.; Kafarski, P. Polyhedron 2002, 21, 321.

13. Rogers, M. J.; Watts D. J.; Russell, R. G. Cancer 1997, 80, 1652.

14. (a) Zhang, Y.; Leon, A.; Song, Y.; Studer, D.; Haase, C.; Koscielski, L. A.; Oldfield, E. J. Med. Chem. 2006, 49, 5804 and references therein. (b) Sanders, J. M.; Song, Y.; Chan, J. M. W.; Zhang, Y.; Jennings, S.; Kosztowski, T.; Odeh, S.; Flessner, R.; Schwerdtfeger, C.; Kotsikorou, E.; Meints, G. A.; Gomez, A. O.; Gonzalez-Pacanowska, D.; Raker, A. M.; Wang, H.; van Beek, E. R.; Papapoulos, S. E.; Morita, C. T.; Oldfield, E. J. Med. Chem. 2005, 48, 2957. (c) Coxon, F. P.; Ebetino, F. H.; Mules, E. H.; Seabra, M. C.; McKenna, C. E.; Rogers, M. J. Bone 2005, 37, 349. (d) Kotsikorou, E.; Oldfield, E. J. Med. Chem. 2003, 46, 2932.

15. Widler, L.; Jaeggi, K.; Glatt, M.; Müller, K.; Bachmann, R.; Bisping, M.; Born, A.; Cortesi, R.; Guiglia, G.; Jeker, H.; Klein, R.; Ranseier, U.; Schmid, J.; Schreiber, G.; Seltenmeyer, Y.; Green, J. J. Med. Chem. 2002, 45, 3721.

16. (a) Hannuniemi, R.; Lauren, L.; Puolijoki, H. Drugs Today 1991, 27, 375. (b) Lin, J. H. Bone 1996, 18, 75. (c) Vepsäläinen, J. J. Curr. Med. Chem. 2002, 9, 1201.

17. (a) Pyrazoles and their benzo derivatives, Elguero, J. In Comprehensive Heterocyclic Chemistry, Katritzky, A. R and Rees, C. W., Eds.; Pergamon Press: Oxford, Vol. 5, 1984, pp 167-303. (b) Pyrazoles, Elguero, J. In Comprehensive Heterocyclic Chemistry II, Katritzky, A. R.; Rees, C. W., and Scriven, E. F. V., Eds.; Pergamon Press: Oxford, Vol. 3, 1996, pp 175. (c) Stadlbauer, W. In Houben-Weyl, Methoden der Organischen Chemie: Indazole (Benzopyrazole), Schaumann, E. Eds.; Georg-Thieme-Verlag Stuttgart: New York, 1994; Vol. E8b, Hetarenes III/2, pp. 764-864. (d) Stadlbauer W. In Science of Synthesis: Indazoles, Neier, R. Eds.; Georg-Thieme-Verlag Stuttgart: New York, 2002; Vol. 2.12.4 (Hetarenes), pp. 227-324. (e) Cerecetto, H.; Gerpe, A.; González, M.; Arán, V. J.; de Ocáriz, C. O. Mini Rev. Med. Chem. 2005, 5, 869. (f) Schmidt, A., Beutler, A.; Snovvdovych, B. Eur. J. Org. Chem. 2008, 4073.

18. Teixeira, F. C.; Ramos, H.; Antunes, I. F; Curto, M. J. M.; Duarte, M. T.; Bento, I. Molecules 2006, $11,867$.

19. (a) Lecouvey, M.; Leroux, Y. Heteroat. Chem. 2000, 11, 556. (b) Rao, D. V. N. S.; Dandala, R.; Lenin, R.; Sivakumaran, M.; Shivashankar, S.; Naidu, A. ARKIVOC 2007, (xiv), 34. (c) Abdou, W. M.; Shaddy, A. A. ARKIVOC 2009, (ix) 143. 
20. Kieczylowski, G. R.; Jobson, R. B., Melillo, D. G.; Reinhold, D. F.; Grenda, V. J.; Shinkai, I. J. Org. Chem. 1995, 60, 8310.

21. (a) Lecouvey, M.; Mallard, I.; Bailly, T.; Burgada, R.; Leroux, Y. Tetrahedron Lett. 2001, 42, 8475. (b) Guénin, E.; Degache, E.; Liquier, J.; Lecouvey, M. Eur. J. Org. Chem. 2004, 2983. (c) Guénin, E.; Monteil, M.; Bouchemal, N.; Prangé, T.; Lecouvey, M. Eur. J. Org. Chem. 2007, 3380.

22. Oelschlager, H.; Ogorka, J.; Kolbeck, I. Arch. Pharm. 1986, 319, 488.

23. (a) Huikko, K.; Kotiaho, T.; Yli-Kauhaluoma, J.; Kostiainen, R. J. Mass Spectrom. 2002, 37, 197. (b) Schroeder, G.; Lyapchenko, N.; Przybylski, R.; Brzezinski, B.; Kozik, T.; Burzyńska, A.; Kafarski, P. J. Mol. Structure 2005, 750, 142. (c) Hardouin, J.; Guénin, E.; Monteil, M.; Caron; M.; Lecouvey M. J. Mass Spectrom. 2008, 43, 1037.

24. (a) Bakhmutova, E. V.; Ouyang, X.; Medvedev, D. G.; Clearfield, A. Inorg. Chem. 2003, 42, 7046. (b) Barja, B. C.; Herszage, J.; Afonso, M. S. Polyhedron 2001, 20, 1821. (c) Silverstein, R. M.; Webster, F. X.; Kiemle; D. J. Spectrometric Identification of Organic Compounds; $7^{\text {th }}$ Ed., John Wiley and Sons, Inc.: New York, 2005, pp 72-126. (d) Lambert, J. B.; Shurvell, H. F.; Lightner, D. A.; Cooks, R. G. Organic Structural Chemistry, PrenticeHall: New Jersey, 1998, pp 151-250. (e) Bauer, S.; Muller, H.; Bein, T.; Stock, N. Inorg. Chem. 2005, 44, 9464. 